\title{
COMPETENCIAS DOCENTES DEL PROFESORADO DE BIOLOGÍA DEL INSTITUTO SUPERIOR DE PRO- FESORADO N 6 LEOPOLDO CHIZZINI MELO. UN ESTUDIO TRANSVERSAL
}

\author{
Jorge Saccone \\ jsaccone@unl.edu.ar \\ Maestría en Didáctica de las Ciencias Experimentales \\ Directora de Tesis: Dra. Claudia Beatriz Falicoff \\ Co-director de Tesis: Dr. Héctor Santiago Odetti \\ Instituto Superior de Profesorado Nº 6 Leopoldo Chizzini Melo - Departamento de Química General e Inorgánica - FBCB - UNL \\ Fecha de defensa: 15 de febrero de 2019
}

\section{RESUMEN}

El objetivo general de la presente tesis de Maestría fue indagar el reconocimiento y valoración de las competencias docentes por parte de los directivos, profesoras y alumnado del Instituto Superior de Profesorado $N^{\circ} 6$ Leopoldo Chizzini Melo, de la ciudad de Coronda, Santa Fe. Se analizaron similitudes y diferencias, en las valoraciones, entre el estudiantado de los cuatro años de la carrera y las profesoras en ejercicio.

Asimismo, se pretendió identificar las competencias docentes presentes en el Diseño Curricular de la Provincia de Santa Fe. Posteriormente, se exploraron relaciones entre las apreciaciones de los directivos, profesoras y el diseño provincial.

En este estudio de caso tipo descriptivo, cuali-cuantitativo y transversal, la muestra de estudio comprendió a los directivos, profesoras y alumnado de $1^{\circ}, 2^{\circ}, 3^{\circ}$ y $4^{\circ}$ año del ciclo lectivo 2015.

A los efectos de indagar las competencias docentes se utilizaron varios instrumentos para recolectar la información, a saber: entrevistas semi-estructuradas, análisis del Diseño Curricular de la provincia de Santa Fe y un cuestionario. Se determinó la fiabilidad del cuestionario mediante el coeficiente Alfa de Cronbach. Se analizó la existencia de similitudes o diferencias en la valoración de las competencias mediante el Test T (Prueba T) de las diferentes poblaciones (alumnado y profesorado).

Luego del análisis de las entrevistas a directivos y profesoras, se percibe que los mismos no logran reconocer las competencias docentes, en su propia formación ni en la que imparten. Ambos grupos coinciden en cuanto a la existencia de falencias en la formación por competencias. Esto se evidencia en la dificultad para definirlas y ejemplificarlas.

Se evidenció una ausencia de competencias específicas para el profesorado de Biología en el Diseño Curricular provincial, aunque se mencionan solo algunas de carácter general.

Aunque las diferencias de las medias no son significativas entre el alumnado de los cuatro años del Profesorado (Apartado C.3.6.2), se perciben mayores y menores preferencias a la hora de valorar las percepciones de las competencias docentes. A medida que se avanza en la carrera, el estudiantado 
otorga una mayor apreciación al grupo de competencias del "saber ser". La valoración del resto de las categorías de competencias es fluctuante en los diferentes años.

La mejor apreciación realizada por las profesoras correspondió a la categoría del "saber ser". Se encontraron algunas diferencias significativas entre la valoración de las profesoras y el alumnado.

ABSTRACT

\section{Teaching competencies of the Biology Teaching Staff of the Higher Institute of Teaching Staff $N^{\circ} 6$ Leopoldo Chizzini Melo. A cross-sectional study}

The general objective of the present master thesis was to delve deeply into the recognition and assessment of teaching competencies performed by authorities, teachers, and students of Instituto Superior de Profesorado Núm. 6 'Leopoldo Chizzini Melo' (Higher Education Institute Nr. 6 'Leopoldo Chezzini Melo'), which is located in the city of Coronda, province of Santa Fe, Argentina. Similarities and differences were analyzed between the assessments made by students from the four levels of the degree program and those provided by teachers practicing their profession at the aforementioned institute. It was also intended to identify teaching competencies found in the Curricular Design of the Province of Santa Fe. Furthermore, the relation among the appreciations made by the institute authorities, teachers, and those found in the provincial design were explored.

In this descriptive case study, which is qualitative, quantitative, and cross-wise, the study sample involved authorities, teachers, and students in the $1^{\text {st }}, 2^{\text {nd }}, 3^{\text {rd }}$, and $4^{\text {th }}$ levels of academic year 2015.

With the aim of inquiring into teaching competencies, various tools were used for collecting data, namely: semi-structured interviews, an analysis of the provincial Curricular Design, and a questionnaire. The questionnaire reliability was measured by using Cronbach's alpha coefficient. The existence of similarities and differences was analyzed in the assessment of competencies by means of a t-test of the involved populations (students and teachers).

After analyzing the interviews made to authorities and teachers, it was noticed that neither of them succeed in recognizing teaching competencies in their own training or in the education they provide. Both groups agree on the existence of failures in competency-based education and training. This is demonstrated by the difficulty in defining and exemplifying those competencies.

The lack of specific competencies for the Biology Teacher's Degree was evidenced in the provincial Curricular Design, even though a few general ones are mentioned.

Even though the differences are not significant among the mean assessments collected from students of the four levels of the teacher's degree program (Section C.3.6.2), more marked and slighter preferences are observed when assessing perceptions of teaching competencies. As students advance along 
the following levels of the degree program, they show greater appreciation of those competencies grouped into the 'know how to be' category. The assessment of the remaining competency categories fluctuates according to the various levels of the degree program.

The best appreciation made by teachers was related to the 'know how to be' category.

Some significant differences were found between the assessments made by teachers and those provided by students. 